\title{
THE USE OF ALCOHOL ADDITIVES FOR ECOLOGICAL GASOLINE PRODUCTION
}

\author{
12345 National Aviation University, 1, Liubomyra Huzara ave.Kyiv, Ukraine 03058 \\ E-mails: ${ }^{1}$ e.valerij.ua@gmail.com; ${ }^{2}$ veranikrud@gmail.com; ${ }^{3}$ mrs.shkiteleva@gmail.com; ${ }^{4}$ ol.ko.ok@ukr.net; ${ }^{5}$ tatianaworknau@ \\ gmail.com
}

\begin{abstract}
The purpose of this article is to perform research to improve the stability, quality and efficiency of gasolinealcohol fuel compositions, as well as obtaining high-octane gasolines corresponding to the modern standards with the addition of alcohols and their mixtures to these gasolines. Research methods: The article considers physicochemical methods for studying the stratification of alcohol-gasoline mixtures, determining the water content in them, as well as determining the octane number of alcohol-gasoline compositions. Results: The raw material base and possibilities of bioethanol production in Ukraine as an ecological additive to gasoline and as a way to increase their octane number were studied. Stratification temperatures of alcohol-gasoline mixtures and octane numbers of A-92 gasoline with different alcohol content were determined. Discussion: It is proposed to use higher concentrations of ethanol (bioethanol) in gasoline mixtures more than $40 \%$ of alcohol, because it does not require dehydration. It is proposed to use an additional fuel pump, which would work only for mixing the fuel mixture, to prevent stratification of the fuel-ethanol composition during its long-term storage in the car's tanks.
\end{abstract}

Keywords: ethanol, bioethanol, alcohol-gasoline mixture, stratification, gasoline, octane number .

Introduction. World oil reserves are declining, its production is becoming more difficult, which leads to higher prices for marketable petroleum products. Therefore, the urgent task for today is to create alternative to oil fuel additives, in which renewable biological resources are used as raw material.

Distilleries in Ukraine can annually produce more than 7.5 million decalitres of bioethanol according to the State Statistics Service of Ukraine.

Table 1 shows the dynamics of ethanol production in Ukraine for 2015-2019 in thousands metric tons (TMT).

Table 1

Dynamics of ethanol production in Ukraine

\begin{tabular}{|c|c|c|c|c|c|}
\hline Year & 2015 & 2016 & 2017 & 2018 & 2019 \\
\hline $\begin{array}{l}\text { E t h a n o I } \\
\text { production, } \\
\text { TMT }\end{array}$ & 249.2 & 219.9 & 185.9 & 173.9 & 149.1 \\
\hline
\end{tabular}

That is, the annual rate of decline in production is $6-15 \%$, the main reasons for which are: low profitability of the alcohol industry due to underutilization of production capacity and the presence of problems with raw materials supply to enterprises.

Increasing alcohol consumption as an alternative additive to gasoline would increase the profitability of the alcohol industry, improve the environmental situation in the country and reduce its energy dependence.

It should be noted that ethanol's heat of combustion is about 30\% less than gasoline's. This affects the power of the engine, and accordingly, the conversion of the car to alcohol fuel will increase its consumption.

There is a phase instability of the mixture in the moisture presence because alcohol is a hygroscopic substance, i.e. the fuel stratification occurs. Although, alcohol-gasoline fuels have become widely used in the United States, Brazil, and fuel stratification is not a problem in their use.

Import to Ukraine satisfies more than $62 \%$ of domestic gasoline consumption and $90 \%$ of diesel fuel, although the potential for bioethanol production is large, but practically not used. $1 \mathrm{~kg}$ of bioethanol production requires about $3 \mathrm{~kg}$ of wheat or corn and about $4 \mathrm{~kg}$ of molasses (by- 
product of sugar beet production, the average annual production of which is 550 thousand tons). It is necessary to produce 200 thousand tons per year of bioethanol with the need for raw materials (wheat, corn) in the amount of only 600 thousand tons, or slightly more than $1 \%$ of annual production of these crops to achieve $10 \%$ of the norm of bioethanol use. The need for grain can be halved when using molasses for production and this will raise the level of sugar beet production in Ukraine [1-4].

\section{Analysis of the research and publications}

Recently, a significant progress happened in research of the bioethanol use as an environmental additive to low-octane gasolines.

It is noted in [5-7] that fuel ethanol does not contain water in contrast to ethanol, from which alcoholic beverages are produced and is obtained by a reduced distillation scheme. That is why it contains fusel oils, aldehydes, methanol, higher alcohols, which makes it unsuitable for consumption for food purposes.

Attempts to use ethanol with hydrocarbons as automotive fuel were in the early XX century. and demonstrated at the International Exhibition in Paris $[3,4]$. Only in the 1970s, that idea was revived due to the catastrophic environmental degradation and oil crisis. This is because renewable raw materials can be used for the production of bioethanol $[6,7]$.

As early as the 1980s, Brazil, the United States, France, Canada, and other countries began using gasolines containing 5 to $20 \%$ vol. ethanol with appropriate labeling (E-5, E-20).

Brazil and the United States are leaders in the production of such fuels among countries of the world $[8,9]$. They produce and sell mixtures of gasoline with ethanol: E10 (10\% by volume), E85 (85\%), E95 (95\%) and pure ethanol E100 for consumption by road transport. Their total share in the world fuel market is $87 \%$. Interest in the use of ethanol in gasoline has increased in post-Soviet countries [8-10].

The production of blended ethanol gasolines and the study of their properties in Ukraine are carried out on the basis of the National Aviation University, National University «Lviv
Polytechnic», Institute of Bioorganic Chemistry and Petrochemistry of NAS of Ukraine, National Transport University, Ukrainian Research Institute of Alcohol and Food Biotechnology [3].

It was noted in our work [4] that alternative fuels are divided into three groups according to the general classification. The first group includes petroleum fuels with additives of non-petroleum origin (alcohols, ethers, etc.), which are close in performance properties to traditional petroleum fuels.

The second group is synthetic liquid fuels, which are similar in properties to traditional petroleum fuels, but they are obtained by processing gaseous, solid or liquid raw materials (natural gas, oil shale, etc.), by processing natural gas into synthesis gas and then into methanol or hydrocarbons by the so-called GTL (Gas to Liquid) technology. The third group is nonpetroleum fuels (alcohols, natural and associated gases, hydrogen, etc.), they differ significantly from traditional fuels in physicochemical and operational properties.

Sometimes there is a need for a slight change in the fuel system of the car when using alternative fuels of the first two groups, the use of fuels of the third group requires significant modernization.

Alternative fuels of the first group are widespread throughout the world. State industry standard GSTU 320.00149943.015-2000 «Mixed motor gasolines. Technical conditions. "), which exists in Ukraine, allows the use of oxygencontaining components and additives in the production of gasoline. It is possible to extract some harmful components such as aromatic compounds or MTBE from the obtained fuel when introduction of ethanol into gasoline, thus ethanol is a high-octane component of the resulting gasoline fuel. Thus, ethanol is a valuable component for the preparation of high-octane unleaded gasoline, especially when regulation of aromatic hydrocarbons and olefins content. The actual octane number of ethanol at compounding is a complex index, as it varies according to the anti-knock properties of the basic fuel. If the octane number of base gasoline is low, the ethanol octane number will be higher when compounding. 
The characteristic of ethanol as a solvent differs from similar characteristics of gasoline due to a polar nature of the functional $\mathrm{OH}$-group. In this regard, ethanol has the ability to dissolve dirt, rust and tar deposits in the components of existing fuel systems.

It was found that ethanol interacts with hydroxyl groups, and the reaction proceeds with a separation of the hydrogen atom from a hydroxyl group of ethanol. The hydrogen atom destroys peroxides due to strong reducing properties; thereby it increases the detonation resistance of the fuel.

The advantages of fuels that contain alcohol include the following properties:

- vapor of ethanol dissipates in air faster than of gasoline;

- ethanol is less toxic than gasoline, it does not contain carcinogenic components;

- ethanol vapor is less flammable than gasoline vapor due to lower selfignition temperature (423 oC compare to $257-300 \mathrm{oC}$ );

- the viscosity of ethanol is higher than of gasoline;

- the electrical conductivity of alcohol is greater than that of gasoline, which reduces the possibility of accumulation of static electricity when pumping fuel ( $\mathrm{Om} / \mathrm{cm}$ vs. Om/ cm);

- octane number of ethanol is higher than of gasoline (108 vs. 75 - 98);

- addition of ethanol results in lower emissions of hydrocarbons;

- ethanol can be obtained from natural renewable raw material, which base is unlimited;

- it reduces the content of the controlled harmful components of vehicle exhaust gas, improves combustion completeness of alcohol mixtures and therefore the emissions of $\mathrm{CO}$ and hydrocarbons are reduced;

- new methods of obtaining ethanol from green plants are developed.

The disadvantages of ethanol as a fuel or a fuel component are:

- corrosion activity (incompatibility with a number of metals and other materials);

- changeability of component composition of ethanol containing fuel caused by evaporation of alcohol, and its extraction from fuel by the water admixture;
- increase of fuel consumption for 3\% at $12 \%$ ethanol concentration;

- increased carbon formation in the presence of acids and aldehydes in the alcohol even in trace amounts [4].

The problem of phase separation of gasolinealcohol mixtures is not removed when using absolute ethyl alcohols. Water flooding of gasoline-alcohol fuel is inevitable in real conditions of storage and transportation due to the access of water into the fuel by different ways [9-10].

\section{Rurpose and objectives of the research}

The main purpose of the work is to carry out research to improve the stability, quality and efficiency of produced gasoline-alcohol fuel compositions, as well as the development of high-octane gasoline compositions with the addition of alcohols and their mixtures that meet modern standards (DSTU).

The main objectives of this work are:

- Determination of the cloud point of the alcohol-gasoline mixture depending on the alcohol content in gasoline A-92 and water concentration in the alcohol;

- Carrying out of research of detonation stability of gasoline with various content of ethanol.

\section{Materials and methodics of research}

4.1. Methodics for determining the cloud point of the alcohol-gasoline mixture

The cloud point (tcp) is called the temperature at which it is possible to see by the naked eye the stratification of the fuel-alcohol mixture when cooling.

The fuel sample is slowly cooled and periodically viewed in the light passing through it to determine the cloud point. In this case, a sample of the same fuel at an ambient temperature is viewed for a comparison.

Equipment, reagents and materials:

- glass test tubes with double walls (2 pcs.);

- mixer;

- cork or rubber plugs;

- Thermometers liquid low-temperature TN-8 ( 2 units) with limits of measurement from -80 to $60{ }^{\circ} \mathrm{C}$ and the scale division value of $1^{\circ} \mathrm{C}$ (for 


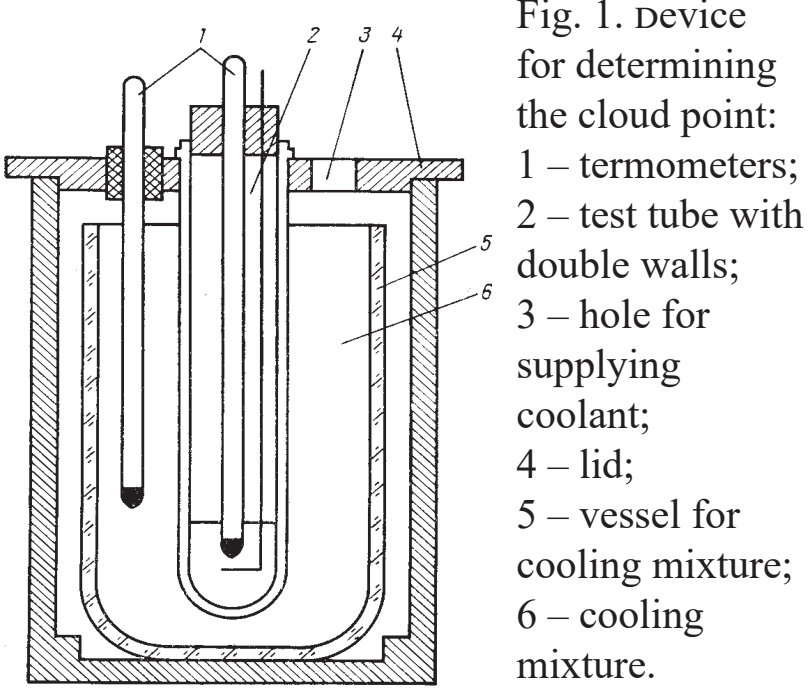

measurement of temperature of the investigated fuel and cooling mixture); $1)$.

- device for determining the cloud point (fig.

- coolant is carbon dioxide.

The first test tube with fuel is left as a reference sample in a test tube rack.

The second test tube with the fuel sample is inserted into a vessel for the cooling mixture. Alcohol is poured through the hole in its lid and dry carbon dioxide is thrown to gradually reduce the temperature.

The fuel is continuously stirred when cooling and its turbidity is monitored compared to the reference sample.

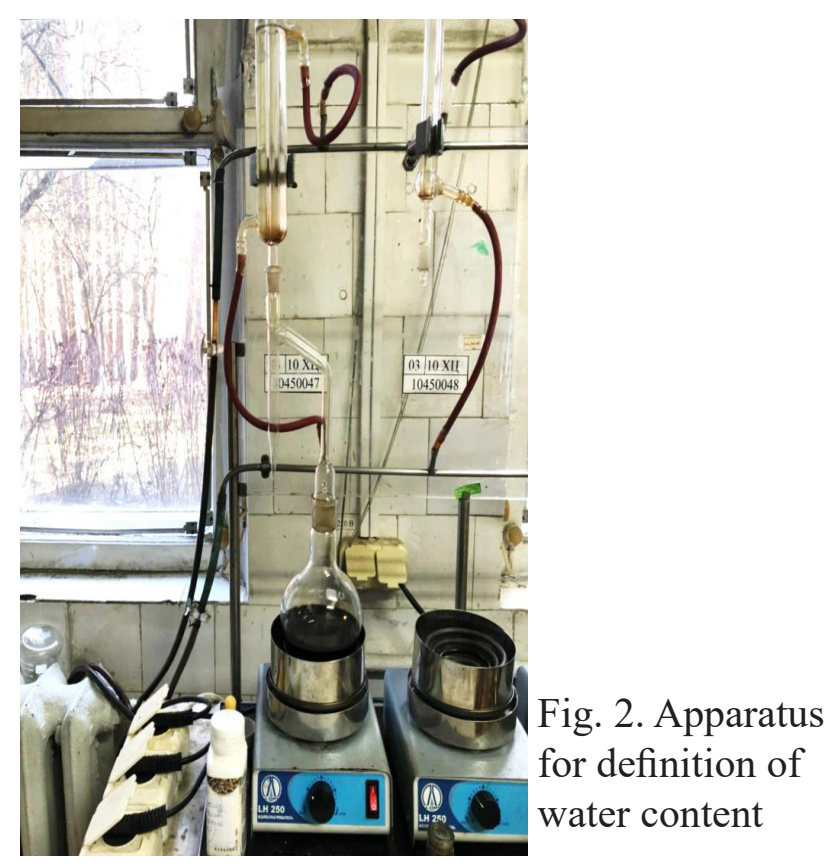

Comparative observations are carried out until the test fuel differs from the reference sample.

4.2. Methodics for determination of water in alcohols and gasoline mixtures

We insert $100 \mathrm{~cm} 3$ of a sample into a round bottom flask.

Then we measure $100 \mathrm{~cm} 3$ of a solvent (benzene) by the graded cylinder and pour it into the flask, mix the mixture in the flask and add a few pieces of unglazed porcelain.

We collect the apparatus for definition of water content (fig. 2) so that to provide tightness of all connections and to exclude leakage of steam and extraneous moisture penetration.

The upper end of the cooler is covered with a loose cotton swab. Cold water is fed to the cooler casing by a supply tap.

We turn on the flask heater. The flask content is brought to a boil and then heated so that the condensation rate of the distillate in the receiver was from 2 to 5 drops in $1 \mathrm{~s}$.

The flask heater is turned off as soon as the volume of water in the receiver-trap will stop increasing and the top layer of a solvent will be completely transparent. The distillation time should vary from 30 to 60 minutes.

Droplets of water left on the walls of the cooler tube push into the receiver-trap with a metal wire.

The apparatus is disassembled when the flask has cooled and the solvent and water have reached room temperature in the trap receiver. We record the volume of water collected in the receiver-trap with accuracy to the nearest one upper mark.

The mass fraction (X) of water in gasoline, $\%$, is calculated by the formula:

$$
\mathrm{X}=\mathrm{V}_{\mathrm{m}}
$$

$\mathrm{V}$ - the volume of water in the trap-receiver, cm3;

$\mathrm{m}$ - mass of the sample taken for testing, $\mathrm{g}$.

This is a more accurate method of determining water content, but it is possible to use alcohol meters for research.

Determination of octane numbers of alcohol-gasoline mixtures was performed on the installation UIT-85 according to standard methodics. 


\section{Research results}

Figure 3 shows the dependence of the cloud point of the gasoline - alcohol mixture on the water content in alcohol for mixtures of different quantitative composition.

As it can be seen from the fig. 3 the residual water content in ethanol can reach $2.5 \%$ vol. when ethanol content is $10 \%$ vol. There is no need to use dehydration in a composition containing more than $40 \%$ vol. alcohol. Thus, we can conclude that it is more efficient to use high concentrations of ethanol in a mixture with gasoline.

The dependence of the octane number of alcohol-containing fuel on the alcohol content in it was studied. As the investigation results showed, this dependence is almost straightforward, which is another advantage of alcohols, which distinguishes them from other anti-knock additives, such as metalcontaining, which have a limit of efficiency at low values of octane number increase. The investigation results are shown in Fig.4.

The antiknock efficiency of individual aliphatic alcohols $\mathrm{C} 1-\mathrm{C} 5$ (octane number, research method according to GOST 8226) is located in the series methanol $>$ ethanol $>$ isopropanol $>$ isobutanol (Fig. 4), which is confirmed by theoretical predictions.

\section{Discussion of the results}

A standard methodics for determining the cloud point of diesel fuels was used to conduct research, which has successfully proven itself in determining the cloud point of alcohol-gasoline mixtures.

As the research results have shown, the cloud point of alcohol-gasoline mixtures shifts towards more positive values with increasing water content in alcohols.

It should also be noted that the cloud point of the fuel mixture is higher at low concentrations of ethanol and its water flooding than at high concentrations of alcohol in gasoline, which
Water content in ethanol, \% vol.

$3,5 \quad 4$
4

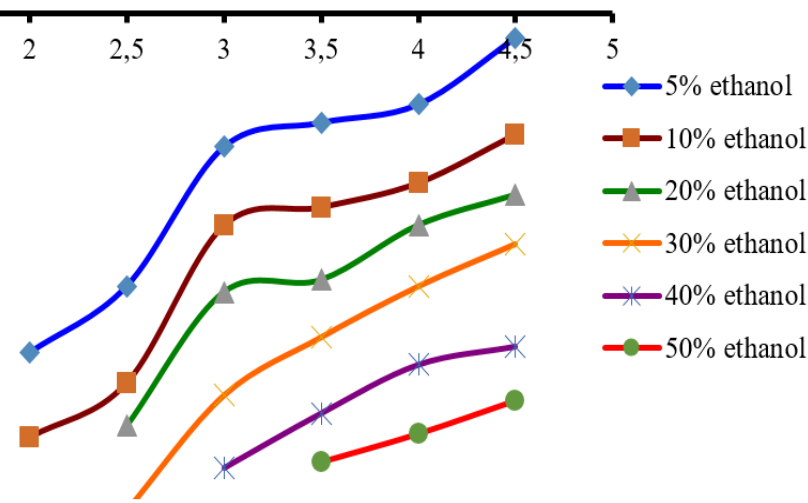

Fig. 3. The dependence of the cloud point of a mixture of gasoline and alcohol on the water content in alcohol

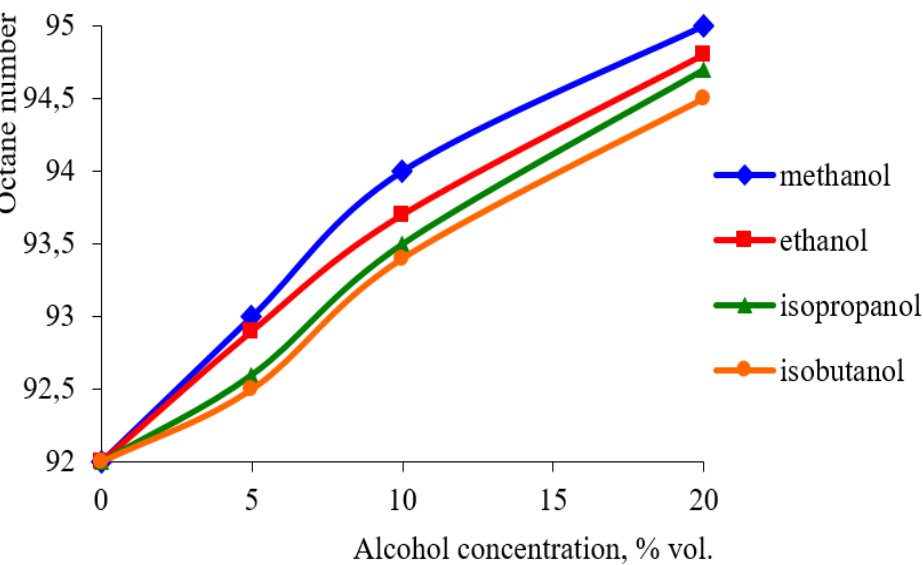

Fig. The dependence of the octane number of the alcoholgasoline mixture on the concentration of alcohol in gasoline A-92

indicates the effectiveness of a mixed fuel with a high ethanol content.

It is possible to use an additional fuel pump to prevent the fuel-alcohol mixture from stratifying during long-term storage in the car's tanks. This fuel pumb will work only to mix the mixture of alcohol and fuel; this does not require complicate technical solutions.

Ethanol has a high octane number - 108 conventional units by the research method, so it is most effective in the row of alcohols in increasing the octane number of gasoline. Thus, when adding about $19 \%$ mass. of ethanol to A-92 gasoline octane number increases to the level of gasoline A-95, which corresponds to the labeling E20.

It is known that detonation in a car engine has a radical-chain mechanism. Alcohols have a high 
resistance to radical cleavage reactions, which decreases with increasing molecular weight of alcohol. The system is structured during compression in the engine. Such structurization causes shielding the most active radical $\mathrm{OH}^{-}$ due to the presence of the hydroxyl group. The influence of the functional group also decreases with increasing length of a hydrocarbon radical. Therefore, the antiknock efficiency of aliphatic alcohols will decrease with increasing mass of the molecule.

\section{Conclusions}

The raw material base and possibilities of bioethanol production in Ukraine as an ecological additive and for increase of octane number of gasolines are investigated.

It was found that there is no need to use ethanol dehydration in the composition with gasoline, which contains more than $40 \%$ vol. of alcohol. That is, it is more efficient to use

\section{References}

[1] Alexey Orzhel and others. Regulation of production of liquid motor fuels. [Office of effective regulation]. Available at: http:// requlation-of-production-of-liquidbiofuels-2019. pdf (accessed 26.08.2021)

[2]Danylov A.M. (2005) Prymenenye prysadok $\mathrm{v}$ toplyvakh [Usage of additives in fuels]. Moskow, Mir Publ., 288 p.

[3] O.Haidai, V. Pilyavskiy, Y. Shelud'ko, Y. Polunkin. (2016) Improvement of performance characteristics of ethanol motor fuels through use of additives based on nanoscale carbon. EUREKA: Physical Sciences and Engineering, no. 6, pp. 3-10.

[4] V. Yefymenko, O.Yefimenko, (2014). [Optimizing the properties of mixed fuel based on compositions hydrocarbon-alcohol]. VI World Congress "Aviation in the XXI-st century». 23-25 September. Kyiv. pp. 5.1.38-5.1.43. (In Ukrainian).

[5] Ratcliff, M., Burton, J., Sindler, P., Christensen, E. et al. (2016) Knock Resistance and Fine Particle Emissions for Several Biomass- high concentrations of ethanol in a mixture with gasoline.

It is shown that the cloud point of alcoholgasoline mixtures shifts towards more positive temperatures with increasing water content in alcohols.

It is proposed to use an additional fuel pump to prevent stratification of the fuel-ethanol mixture during its long-term storage in the car's tanks, which will work only for mixing the mixture of alcohol and fuel. This is not a complicate technical solution.

It was confirmed the efficiency of using ethanol (bioethanol) as a high-octane and environmentally friendly additive to gasoline. When adding about $19 \%$ mass. ethanol to gasoline A-92 octane number increases to the level of gasoline A-95, which corresponds to the labeling E20. Thus, the use of ethanol (bioethanol) as a renewable energy source solves not only environmental but also energy problems.

Derived Oxygenates in a Direct-Injection SparkIgnition Engine. SAE Int. J. Fuels Lubr., no. 9(1), pp. 59-70.

[6] Barakat Y., Awad E. N., Ibrahim V. (2016) Fuel consumption of gasoline ethanol blends at different engine rotational speeds. Egyptian Journal of Petroleum, no. 25, pp. 309-315.

[7] Thangavelu S.K., Ahmed A. S., Ani F. N. (2016) Review on bioethanol as alternative fuel forsparkignition engines. Renew SustainEnergy Rev., no. 56, pp. 820-835.

[8] Larsen U., Johansen T., Schramm J. Ethanol as a fuel for road transportation. Available at: https://www.iea-amf.org/app/webroot/files/ file/Annex\%20Reports/AMF_Annex_35-1.pdf (accesed 14.09.2021).

[9] Elfasakhany A. (2017) Alcohols as Fuels in Spark Ignition Engines: Second Blended Generation. Munchen, Lambert Academic Publ., $235 \mathrm{p}$.

[10] Agarwal A.K. (2007) Biofuels (alcohols and biodiesel) applications as fuelsfor internal combustion engines. Progress in Energy and Combustion Science, no. 33, pp. 233-271. 
В.В. Сфименко ${ }^{1}$, В.М. Руденко ${ }^{2}$, О.С. Тітова ${ }^{3}$, О.І, Косенко ${ }^{4}$, Т.В. Кравчук ${ }^{5}$

Використання спиртових добавок для виробництва екологічних бензинів

12 Національний авіаційний університет, просп. Любомира Гузара, 1, Київ, 03058, Україна

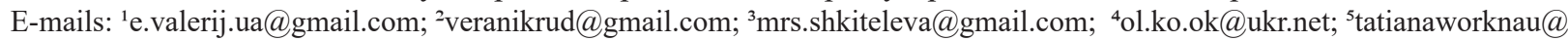
gmail.coma

Метою даної статті є проведення досліджень по підвищення стабільності, якості та економічності застосовуваних бензино-спиртових паливних композичій, а також одержання високооктанових бензинів з додаванням спиртів та їх сумішей, які задовольняють сучасним вимогам стандартів. Методи: У статті розглянуто фізико-хімічні методи дослідження розшарування спирто-бензинових сумішей, визначення вмісту в них води, а також визначення октанового числа спирто-бензинових композицій. Результати: Досліджена сировинна база та можливості виробництва біоетанолу в Украйні в якості екологічної добавки до бензинів та для підвищення їх октанового числа, визначені температури розшарування спирто-бензинових сумішей та октанові числа бензину А-92 з різним вмістом спиртів. Обговорення: Запропоновано використання більш високі концентрації етанолу (біоетанолу) в сумішах з бензином, понад 40 \% спирту, оскільки при иьому немає необхідності проводити його зневоднення. Запропоновано для запобігання розшарування паливно-етанольної композииії при ї̈ тривалому зберіганні в баках автомобіля застосувати додатковий паливний насос, який буде праџювати лите для перемімування паливної сумімі.

Ключові слова: етанол, біоетанол, спирто-бензинова суміш, розшарування, бензин, октанове число.

\section{В.В. Сфименко ${ }^{1}$, В.М. Руденко ${ }^{2}$, О.С. Титова ${ }^{3}$, О.В, Косенко ${ }^{4}$, Т.В. Кравчук Использование спиртовых добавок для производства экологических бензинов \\ 12 Национальный авиационный университет, просп. Любомира Гузара, ${ }^{1}$, Киев, Украина E-mails: ${ }^{1}$ e.valerij.ua@gmail.com; ${ }^{2}$ veranikrud@gmail.com; ${ }^{3} \mathrm{mrs}$. shkiteleva@gmail.com; ${ }^{4}$ ol.ko.ok@ukr.net; ${ }^{5}$ tatianaworknau@ gmail.com}

Целью данной статьи является проведение исследований по повышению стабильности, качества и экономичности применяемых бензино-спиртовых топливных композиции, а также получения высокооктановых бензинов с добавлением спиртов и их смесей, которые удовлетворяют современным требованиям стандартов. Методы: В статье рассмотрены физико-химические методы исследования расслоение спирто-бензиновых смесей, определение содержания в них воды, а также определения октанового числа спирто-бензиновых композиций. Результаты: Исследована сырьевая база и возможности производства биоэтанола в Украине в качестве экологической добавки к бензинам и для повымения их октанового числа, определенные температуры расслоения спирто-бензиновых смесей и октановые числа бензина А-92 с различным содержанием спиртов. Обсуждение: Предложено использовать более высокие конщентрации этанола (биоэтанола) в смесях с бензином, более 40\% спирта, так как при этом нет необходимости проводить его обезвоживания. Предложено для предотвращения расслоения топливно-этанольной композиции при ее длительном хранении в баках автомобиля применить дополнительный топливный насос, который будет работать только для перемешивания топливной смеси.

Ключевые слова: нэтанол, биоэтанол, спирто-бензиновая смесь, расслоение, бензин, октановое число. 


\section{AUTHORS:}

Valerii Volodymyrovych Yefymenko. (1960)

Candidate of technical sciences, Docent.

Associate Professor of the Department of Chemistry and Chemical Technology, Faculty of Environmental Safety, Engineering and Technologies, National Aviation University, Kyiv, Ukraine.

Education: Kyiv Institute of Engineers of Civil Aviation, Ukraine (1984).

Research area: fuels, lubricants, performance properties, chemical technology

Publications: 90

Olena Ivanivna Kosenko. (1957), Candidate of Chemical Sciences, Docent.

Associate Professor, Department ofChemistry and Chemical Technology, Faculty of Environmental Safety, Engineering and Technology, National Aviation University, Kyiv, Ukraine

Education: Kyiv Polytechnic Institute, Ukraine (1982).

Field of research: chemical technology of fuels and carbon materials, chemistry of adsorption materials, catalysis

Publications: 70

Vira Mykolaevna Rudenko. (1940) Doctor of Technical Sciences, Professor.

Professor of the Department of Chemistry and Chemical Technology, Faculty of Environmental Safety, Engineering and Technology, National Aviation University, Kyiv, Ukraine Education: Kyiv Technological Institute of Food Industry, Ukraine (1964).

Field of research: chemistry, chemical technologies

Publications: 117
Olga Samiylivna Titova. (1953) Candidate of Chemical Sciences, Docent.

AssociateProfessor, Department of Chemistry and Chemical Technology, Faculty of Environmental Safety, Engineering and Technology, National Aviation University, Kyiv, Ukraine

Education: Kyiv State University named after T.G. Shevchenko, Ukraine (1977).

Field of research: petrochemistry, fuel chemistry Publications: 86

Tetiana Volodymyrivna Kravchyk. (1986)

Deputy Dean of the Faculty of Environmental Safety, Engineering and Technologies, National Aviation University.

Graduated from the National Aviation University, Kyiv, Ukraine, (2009).

Direction of a scientific activity: chemical thermodynamics and thermochemistry.

Publications: 16. 